Vol 11, Issue 8, 2018

\title{
HISTOPATHOLOGICAL LIVER TISSUES OF ALLOXAN-INDUCED WISTAR RATS THAT GIVEN LAWSONIA INERMIS (LINN.) LEAVES' ETHANOLIC EXTRACT
}

\author{
MUTIARA INDAH SARI ${ }^{1 *}$, DWI RITA ANGGRAINI ${ }^{2}$ \\ ${ }^{1}$ Department of Biochemistry, Faculty of Medicine, Universitas Sumatera Utara Jl. Dr. Mansur Kampus USU Medan 20155, Indonesia. \\ ${ }^{2}$ Department of Anatomy, Faculty of Medicine, Universitas Sumatera Utara Jl. Dr. Mansur Kampus USU Medan 20155, Indonesia. \\ Email: muti_dr@yahoo.com
}

Received: 19 February 2018, Revised and Accepted: 24 April 2018

ABSTRACT

Objectives: The aim of this research was to see the effect of Lawsonia inermis (Linn.) leaves ethanolic extract (LLEE) on liver histopathological of alloxan-induced Wistar rats.

Methods: Thirty-five of male Wistar rats grouped into five groups, i.e., K (normal) given $0.9 \% \mathrm{NaCl}$ solution and P1-P4 were induced using alloxan (120 mg/kg BW) intraperitoneally. P2-P4 was given LLEE, i.e., $200 \mathrm{mg} / \mathrm{kg} \mathrm{BW,} 400 \mathrm{mg} / \mathrm{kg}$ BW, and $600 \mathrm{mg} / \mathrm{kg}$ BW for 28 days. On $29^{\text {th }}$ day, all Wistar rats of the group were sacrificed to take its liver. Histology preparation of liver by paraffin slicing method of hematoxylin-eosin staining. The observation was done under a microscope with $\times 40$ and $\times 100$ magnification. Observation of the liver histopathological includes changes of the central venous, sinusoid, hepatocyte morphology, and glycogen accumulation, P1-P4 compared to K.

Result: The results showed that in P4 group, LLEE dose $600 \mathrm{mg} / \mathrm{Kg}$ BW for 28 days able to improve liver tissues structure of alloxan-induced Wistar rats.

Conclusion: The LLEE at dose $600 \mathrm{mg} / \mathrm{Kg}$ BW effective can restore the liver destruction of alloxan-induced Wistar rats.

Keywords: Lawsonia inermis (Linn.), Histopathological, Liver.

(C) 2018 The Authors. Published by Innovare Academic Sciences Pvt Ltd. This is an open access article under the CC BY license (http://creativecommons. org/licenses/by/4. 0/) DOI: http://dx.doi.org/10.22159/ajpcr.2018.v11i8.25358

\section{INTRODUCTION}

Diabetes mellitus (DM) is metabolic disorders due to carbohydrate, lipid, and protein metabolism. DM occur due to impaired productivity otsecretion or function of insulin, cause hyperglycaemia [1]. Chronic hyperglycemia will increase the production of free radicals. Free radical compounds related to damaging, dysfunction, and disorders of the liver [2]. Since a long time ago, Lawsonia inermis (Linn.)/LL was used by people in all the world to treat disorders of increased blood glucose levels (hyperglycemia) [3].

LL leaves contain naphthoquinones, tannins, naphthalenes, and flavonoid. The flavonoids can be the function of radical scavengers because they can against the free radicals in the body. Need to research to get the function of this plant as a source of natural bioactive compounds. Therefore, it is a potential raw material for medicine [3].

Based on the background, the aim of this study research was to see the effect of L. inermis (Linn.) leaves ethanolic extract (LLEE) on the liver histopathological representation of alloxan-induced hyperglycemia Wistar rat model. Given alloxan is the fastest method to produce experimental hyperglycemia conditions [4]. Administration of alloxan as experimental hyperglycemia in animal model will cause liver tissue damage [5].

\section{METHODS}

A research ethical permit is obtained from the Ethics Committee of the Faculty of Mathematics and Natural Sciences (FMIPA), Universitas Sumatera Utara (USU), Medan (Number of Ethical Clearance was 116 by 2017). The research was conducted at Biology Laboratory of FMIPA USU, Chemistry Laboratory of FMIPA USU, and Pathology Anatomic Laboratory of Faculty of Medicine, USU.

This research used Wistar rats (Rattus norvegicus), with inclusion criteria: Male sex, age 2-3 months, BW ranging from 150 to $200 \mathrm{~g}$, and has not been used for other research. The Wistar rats were excluded if they died during the research. The number of Wistar rats used was 35 Wistar rats. The Wistar rats were grouped into five groups according to the Federer formula [6]. The group of Wistar rats in the research was negative control (K), positive control (P1), and LLEE extract treatment groups with doses $200 \mathrm{mg} / \mathrm{Kg} \mathrm{BW}$ (P2), $400 \mathrm{mg} / \mathrm{Kg}$ BW (P3), and $600 \mathrm{mg} / \mathrm{Kg} \mathrm{BW}$ (P4) [7,8]. After 1 week of acclimation, P1, P2, P3, and P4 groups were induced alloxan $120 \mathrm{mg} / \mathrm{Kg}$ BW in 0.1 $\mathrm{M}$ citric buffer by intraperitoneal injection to cause conditions of rat hyperglycemia $[9,10]$.

\section{Preparation of LLEE}

Ethanolic extraction of LL was done with maceration method that used ethanol solvent with ratio 1:10 (w/v). The dried LL was dissolved by ten parts after that poured with 75 parts of ethanol $96 \%$ as the essenced, closed and left for 5 days, and shielded from the light while stirring occasionally. After 5 days, the solution was filtered, and the pulp was squeezed and washed with enough liquid essence to obtain 100 parts. The extract was obtained evaporated at a temperature of $50^{\circ} \mathrm{C}$ [7]. On the $1^{\text {st }}$ day after hyperglycaemia happened, LLEE was given to the groups of Wistar rat P2, P3, and P4 groups with doses of each group $200 \mathrm{mg} / \mathrm{Kg} \mathrm{BW}, 400 \mathrm{mg} / \mathrm{Kg} \mathrm{BW}$, and $600 \mathrm{mg} / \mathrm{Kg} \mathrm{BW}$. The treatment was performed for 28 days, and the Wistar rats were sacrificed with light chloroform anesthesia on the day $29^{\text {th }}$. The result of sectioning tissue from liver rats was taken as sample.

\section{Surgery of Wistar rats}

A surgical procedure was performed through preparation, surgery, and sanitation by the routine procedure at Laboratory of Biology, FMIPA, USU. At the stage of surgical, the Wistar rats were killed by neck dislocation after neck after light chloroform anesthesia. The liver organ was taken by surgical and then using $0.9 \% \mathrm{NaCl}$ cleaned and put in the pot containing $10 \%$ formalin buffer. 
Preparation histology slides of liver Wistar rats

The preparation histology slides of liver Wistar rats were done in at the Pathology Anatomic Laboratory of Faculty of Medicine, USU, by routine histology method. The stages of preparation are as follows on stage, i.e., fixation, dehydration, clearing, embedding, blocking, sectioning, staining gluing (mounting), labeling, and observation.

Slides were observed under a microscope with $\times 40$ and $\times 100$ magnification at the Pathology Anatomic Laboratory of Faculty of Medicine, USU. Records of the histological results were obtained by photomicrography using the digital photomicrographic microscope.

\section{Data analysis}

The histopathological of liver cell was analyzed with reading the qualitatively descriptive based on the central venous, sinusoid, hepatocyte morphology, and glycogen accumulation (GA) by looking at the liver picture in each $\mathrm{P} 1, \mathrm{P} 2, \mathrm{P} 3$, and $\mathrm{P} 4$ groups compared to the normal control $(\mathrm{K})$

\section{RESULTS}

The effect of LLEE on the liver of hyperglycemic wistar rats can be seen by hematoxylin-eosin (HE) staining. Histologic examination of the liver of wistar rats shows in Figs. 1-6

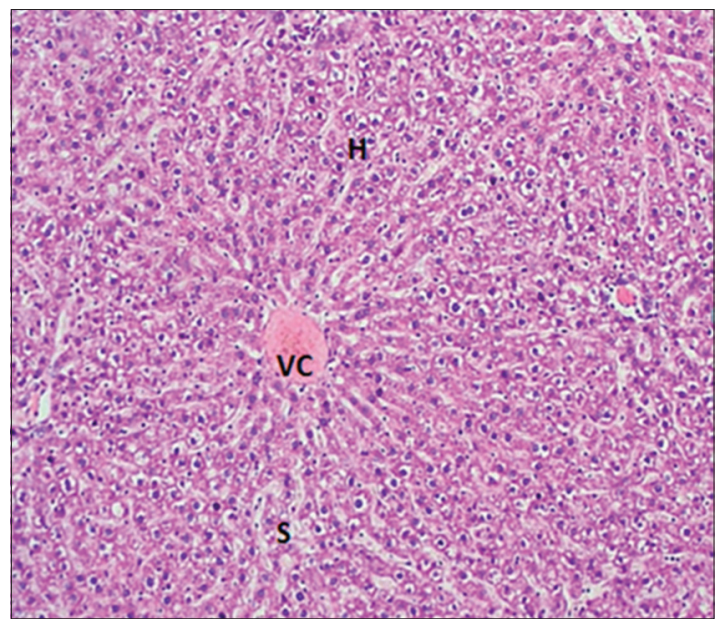

Fig. 1: The liver tissue showed normal cellular hepatocyte architecture. Vena central, H (Hepatocyte), S (Sinusoid) ( $\mathrm{H}$ and $\mathrm{E}, \times 40$ )

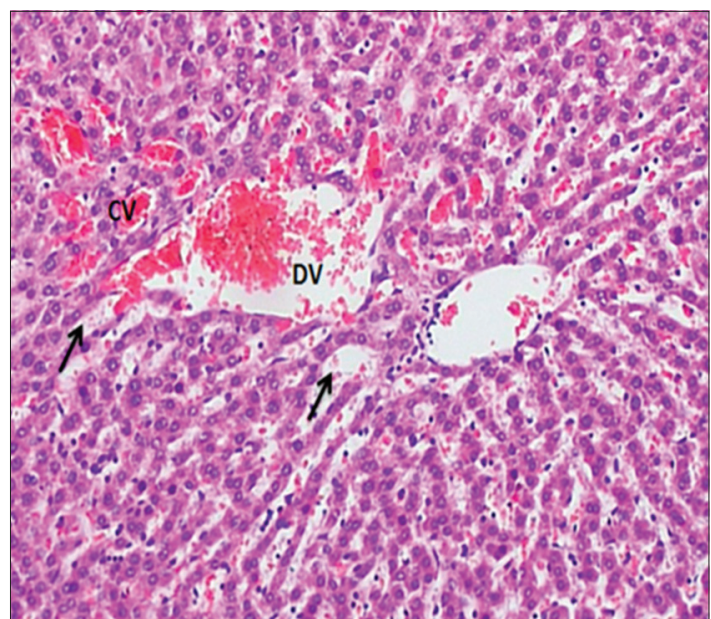

Fig. 2: The liver tissue (P1) with irregular hepatocyte, sinusoid space dilatated (arrow), glycogen accumulation, and congestion and dilatation of vena central $(\mathrm{H}$ and $\mathrm{E}, \times 100)$
Fig. 1 is negative control $(\mathrm{K})$ of the liver tissue Wistar rats group showing normal cellular hepatocyte architecture.

Figs. 2 and 3 are positive/diabetic control (P1) of the liver tissue induced with $120 \mathrm{mg} / \mathrm{Kg} \mathrm{BW}$ of alloxan showed cellular abnormalities with irregular hepatocyte, widened sinusoid space, GA, and congestion and dilatation of vena central.

Fig. 4 is liver tissue treated with LLEE at dose $200 \mathrm{mg} / \mathrm{Kg}$ BW (P2) showed a similarly with diabetic control appearance, not much change.

Fig. 5 is tissue treated with LLEE at dose $400 \mathrm{mg} / \mathrm{Kg} \mathrm{BW} \mathrm{(P3)} \mathrm{showed}$ a slight cellular hepatocyte regeneration, a slightly widened sinusoid space, and decreased congestion of vena central.

Fig. 6 is liver tissue treated with LLEE at dose $600 \mathrm{mg} / \mathrm{Kg} \mathrm{BW}$ (P4) showed complete restoration compare to the normal control.

\section{DISCUSSION}

In this research, the histopathological of the liver of wistar ratson P1P4 groups that induced of alloxan compared with the negative control group (K) showed abnormalities. Abnormalities are seen in the central venous,, sinusoids, morphological hepatocytes and GA. The induction

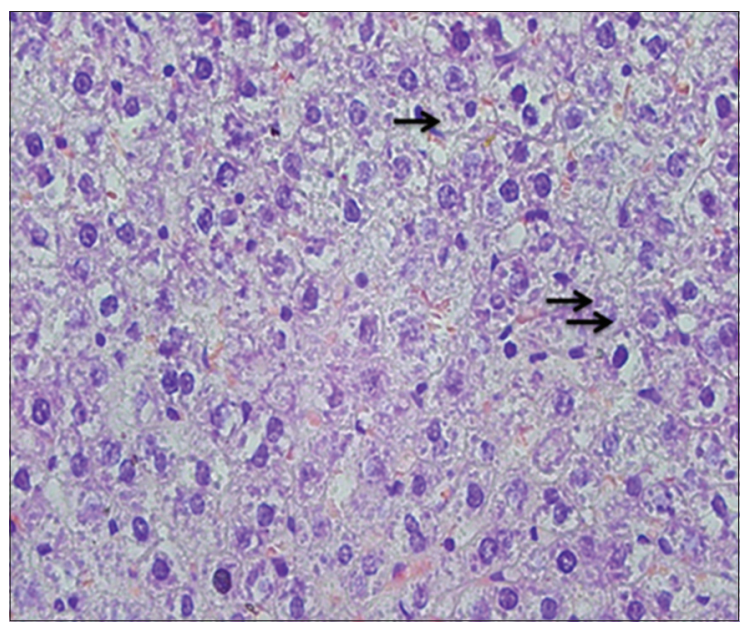

Fig. 3: The liver tissue (P1) showed irregular hepatocyte and glycogen accumulation (arrow) (H and E, ×100)

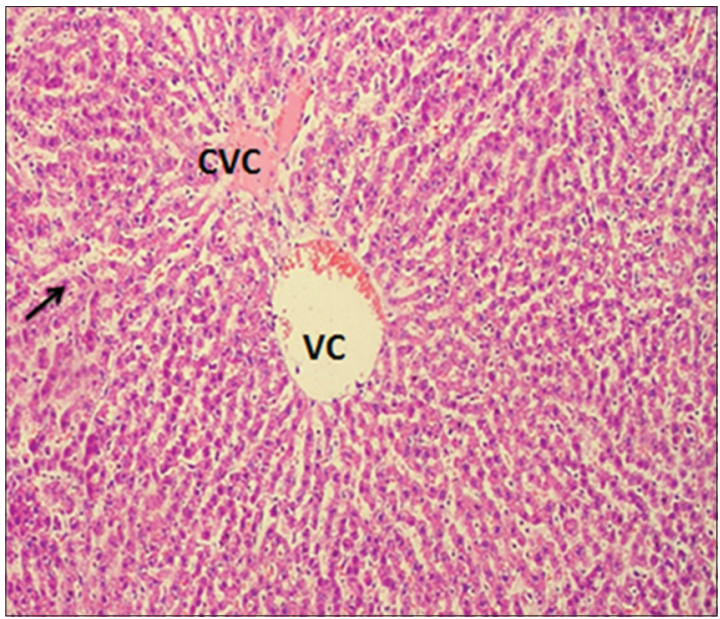

Fig. 4: The liver tissue treated with ethanolic extract of Lawsonia inermis (Linn.) leaves at dose $200 \mathrm{mg} / \mathrm{kg}$ bw (P2) showed a similarly with diabetic control appearance, not much change, dilatated sinusoid space (arrow), congestion of vena central (H and E, x40) 


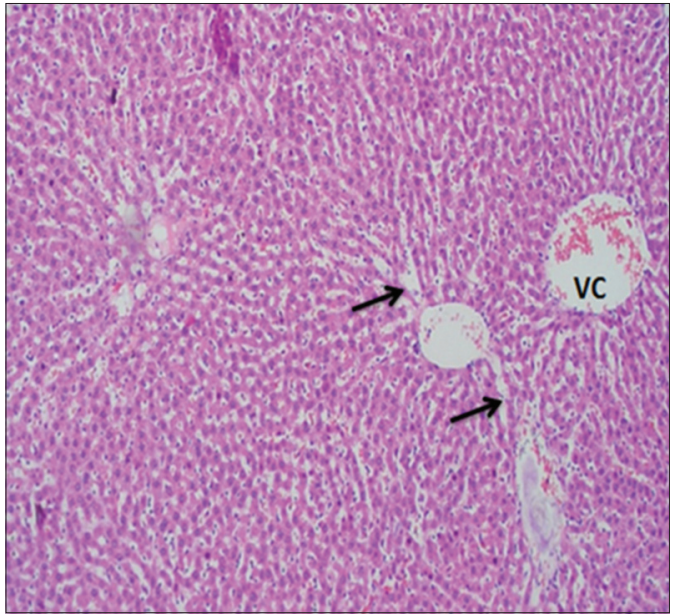

Fig. 5: The liver tissue treated with ethanolic extract of Lawsonia inermis (Linn.) leaves at dose $400 \mathrm{mg} / \mathrm{kg} \mathrm{BW}$ showed a slight cellular hepatocyte regeneration, a slight sinusoid space dilatated (arrow), and decreased congestion of vena central (H and $E, \times 40)$

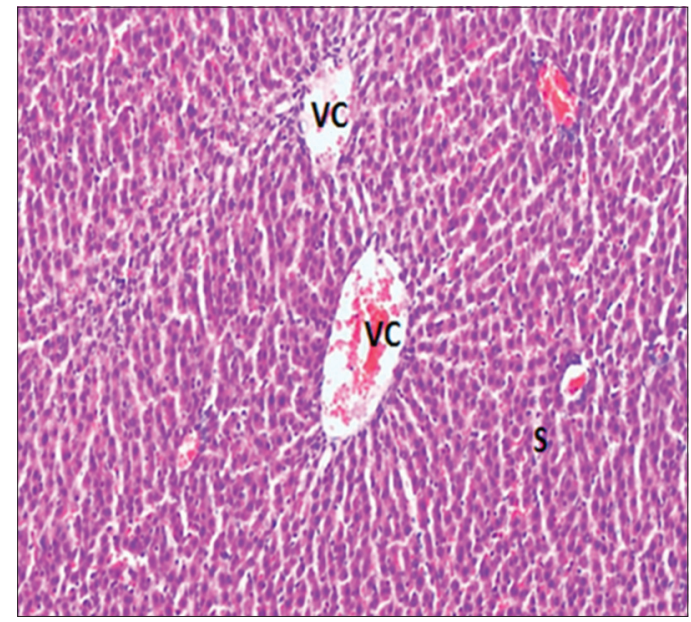

Fig. 6: The liver tissue showed a normal cellular architecture (H and $\mathrm{E}, \times 40$ )

of alloxan can cause a diabetic state in experimental animals and at certain doses of alloxan will cause tissue damage in the liver. The liver is an important organ in the body and has a central role in the metabolism of substances and substances that are toxic in the body. This causes the liver to become an organ that is susceptible to metabolic system disorders. Indications of disorder can be seen in changes in liver histologic structures such as abnormalities on the central venous, sinusoids, hepatocyte morphology, and GA [11]. Damage to liver cells can be permanent damage and temporary. On temporary damage, the liver cells will undergo a change as a form of adaptation process. This temporary change can be recovered by treatment [12].

The treatment by utilizing natural resources such as herb plants has become a tradition of people around the world. Traditional medicine comes from the herb plant that has safe side effect compared to the chemical medicine $[13,14]$. There have been many studies conducted in conjunction with the treatment of DM, one of them with the utilization of herb plants. In this research, the effect of LLEE shows on the histopathological of the liver tissue Wistar rats of P2-P4 groups compared to K and P1 groups. Effect of LLEE extract treatment is shown in Figs 4-6.

On Fig. 4 can be seen the liver of wistar rats treated with LLEE at dose $200 \mathrm{mg} / \mathrm{kgBW}$ (P2) is not much change. The appearance of P2 group showed a similarly to the diabetic control appearance (P1 group). Fig. 5 is hepatic tissue treated with LLEE at dose $400 \mathrm{mg} / \mathrm{kg}$ BW (P3) which shows a slight cellular hepatocyte regeneration, a slight widened sinusoid space, and decreased congestion of venous centralis. Fig. 6 is hepatic tissue treated with LLEE at dose $600 \mathrm{mg} / \mathrm{kg}$ BW (P4) which shows complete restoration compare to the normal control (K group).

LL is a herb plant that is often used as a medicine by local residents to treat disorders of increased blood glucose levels. LL is native to tropical and sub-tropical plants such as Asia, South Africa, East Africa, and North Africa. In Medan city, the capital city of North Sumatra Province, the plants much grow a lot in Medan Denai, one of the districts. LL is one of 40 types of plants used as medicines and is listed in the list of drugs "Ebers Papyrus" written in 1550 SM Leaves are small, greenish brown to the dull green, opposite in arrangement along the branches with short petioles, about $1.5-5 \mathrm{~cm}$ long and $0.5 \mathrm{~cm}$ wide to $2 \mathrm{~cm}$. The main component of the leaf is a dye substance known as legal one, 2-hydroxy1,4-naphthoquinone-C10H603 [15].

The LL has beneficial of antioxidant [16]. The active compound as an antioxidant in LL is flavonoid. Flavonoids can inhibit the activity of alpha-glucosidase enzymes. Flavonoids are phenol compounds that widely held by plants and function as inhibitors of alpha-glucosidase enzymes. Potential flavonoid agents used for the treatment of conditions of rat hyperglycemia in this research because the relevant of alpha-glucosidase enzyme inhibitors reduce the complex of digestion carbohydrates and absorb, thereby reducing elevated glucose levels [17]. The flavonoids can be the function of radical scavengers because they can capture the free radicals in the body. The mechanism system of flavonoids was the conjugated bond and $\mathrm{H}$ atom as the donor of the hydroxyl $(-\mathrm{OH})$ phenolic [18]. This natural antioxidant can fight the damaging caused by free radicals, improving the function of organs, such as liver in this research.

Previous studies have demonstrated the phytochemical test on plant extracts of herbs that constituents such as alkaloids, glycosides, tannins, saponins, flavonoids, carbohydrates, steroids, triterpenoids, and phenolic compounds enhance hepatoprotective efficacy [19].

\section{CONCLUSIONS}

The results showed that LLEE dose $600 \mathrm{mg} / \mathrm{Kg}$ BW for 28 days is able to improve liver tissue structure of hyperglycemia Wistar rats induced by alloxan.

\section{CONFLICTS OF INTERESTS}

Authors declare that they have no conflicts of interest regarding this research.

\section{AUTHOR'S CONTRIBUTION}

Mutiara Indah Sari: Designing the methodology of research, collecting and preparing the sample histopathology tissue, and writing the manuscript. Dwi Rita Anggraini: Analyzing the result of histopatology, and writing the manuscript.

\section{ACKNOWLEDGMENTS}

The authors gratefully acknowledge that the present research is supported by the USU.

\section{REFERENCES}

1. World Health Organization. Global Report on Diabetes; 2016

2. Sheikhpour R. Diabetes and oxidative stress: The mechanism and action. Iran J Diabetes Obesity 2013;5:40-5.

3. Badoni Semwal R, Semwal DK, Combrinck S, Cartwright-Jones C, Viljoen A. Lawsonia inermis L. (henna): Ethnobotanical, phytochemical and pharmacological aspects. J Ethnopharmacol 2014;155:80-103.

4. Fitrianda E, Sukandar EY, Elfahmi, Adnyana IK. Antidiabetic activity of extract, fractions, and asiaticoside compound isolated from Centella 
asiatica Linn. Leaves in alloxan-induced diabetic mice. Asian J Pharm Clin Res 2017;10:268-72.

5. Sutrisna EM, Sahadewa FA, Ardiansyah I. Effect of ethanolic extract of Tinospora crispa L from Indonesia in alloxan induced liver damage. Int J Pharm Pharm Sci 2017;9:65-8.

6. Federer W. Statistics and Society: Data Collection and Interpretation. $2^{\text {nd }}$ ed. New York: Marcel Dekker; 1991.

7. Chikaraddy A, Maniyar Y, Mannapur B. Hypoglycemic activity of ethanolic extract of Lawsonia inermis Linn. (Henna) in alloxan induced diabetic albino rats. Int J Pharm Biol Sci 2012;2:287-92.

8. Sari MI, Ilyas S, Widyawati T, Antika MA. Effect of Lawsonia innermis (linn) leaves ethanolic extract on blood glucose and malondialdehyde level in alloxan-induced diabetic rats. IOP Conf Ser Earth Environ Sci 2018;130:12034.

9. Chougale AD, Panaskar SN, Gurao PM, Arvindeka AU. Optimization of Alloxan Dose is Essential to Induce Stable Diabetes for Prolong Period; 2007. Available from: http://www.sciarlet.net/ fulltext/?doi=ajb2007.402.408. [Last cited on 2016 Aug 10].

10. Sari MI, Antika MA, Anggraini DR. Blood glucose levels and the microscopic structure of kidney wistar rat diabetes mellitus under the effect of Lawsonia innermis (Linn) leaves ethanolic extract. Asian J Pharm Clin Res 2018;11:257-61.

11. Zimmerman HJ. Chemical hepatic injury and its detection. J Liver Toxicol 1982;25:207-36.

12. Etuk EU. Animals Models for Studying Diabetes Mellitus. Sokoto,
Nigeria: Department of Pharmacology College of Health Sciences, Usmanu Danfodiyo University; 2010.

13. Rao MO, Sreenivasulu M, Chengaiah B, Reddy KJ, Chetty MC. Herbal medicines for diabetes mellitus: A review. Int J PharmTech Res 2010;2:1883-92

14. Sari MI, Rahmat NB, Wijaya DW. Effect of Prunus dulcis extract against total cholesterol level in mice that given monosodium glutamate. IOP Conf Ser Mater Sci Eng 2017;288:12097.

15. Kumar S, Singh Y, Singh M. Agro-history, uses, ecology and distribution of Henna (Lawsonia inermis L. syn. Alba Lam). Henna: Cultivation. Improvement and Trade. Jodhpur, India: Central Arid Zone Research Institute; 2005. p. 11-2

16. Uddin N, Siddiqui BS, Begum S, Bhatti HA, Khan A, Parveen S, et al. Bioactive flavonoids from the leaves of Lawsonia alba (Henna). Phytochem Lett 2011;4:454-8.

17. Shafi S, Tabassum N. Phytochemical screening and renal effects of ethanolic extract of Eriobotrya japonica fruits and seeds in alloxan induced diabetic rats. Int J Curr Pharm Res 2018;10:3-7.

18. Engineer AS, Pal S, Desai KR, Highland HN. Synergistic antioxidant action of Murraya koenigii and Plumeria rubra extracts enhance hepatoprotective efficacy against methotrexate induced liver injury. Int J Pharm Pharm Sci 2017;9:152-9.

19. Priya G. Antioxidant mediated defense role of Eclipta alba herbal extract against Ccl4 inducedtoxic hepatitis. Int J Curr Pharm Res 2018;10:29-32. 